\title{
New technology to obtain 1-methyl-5-pnenyl-7-chloro- 1,3-dihydro-2H-[1,4]-benzodiazepine-2-one
}

\author{
(C) Natalya I. Lyukshenko, ${ }^{*+}$ Roman G. Nikitin and Yury V. Morozhenko \\ Federal Research and Production Center "Altai". Socialisticheskaya St., 1. Biysk, 659322. \\ Altai Region. Russia. Phone: +7 (3854) 30-19-05. E-mail: post@frpc.secna.ru
}

\begin{abstract}
*Supervising author; ${ }^{+}$Corresponding author
Keywords: 1-methyl-5-phenyl-7-chloro-1,3-dihydro-2H-[1,4]-benzodiazepine-2-one, condensation, 2-benzoyl-2',4-dichloro- $N$-methylacetanilide, synthesis,

5-chloro-2-methylaminobenzophenone, 1,4-benzodiazepines.
\end{abstract}

\begin{abstract}
At present, benzodiazepine derivatives being used widely, they continue to occupy a leading position among the drugs of the anxiolytic group. Most anxiolytics of the benzodiazepine structure are derivatives of 1,4benzodiazepine. The basis of the chemical benzodiazepine structure consists of a benzene ring connected to a seven-membered heterocyclic ring containing two nitrogen atoms (diazepine) at positions 1 and 4 . All the benzodiazepine derivatives used in the clinic also have a second benzene ring attached to carbon. The presence of a halogen or a nitro group is essential to display its activity.

Diazepam (1-methyl-5-phenyl-7-chloro-1,3-dihydro-2H-[1,4] benzodiazepin-2-one) is in the list of necessary and important medicinal products. The urgent issue is the development of a new method to synthesize 1methyl-5-phenyl-7-chloro-1,3-dihydro-2H-[1,4]-benzodiazepines-2-one that would allow producing the drug in the required quantities and for mass consumption.

The search for possible effective ways of synthesizing 1-methyl-5-phenyl-7-chlorine-1,3-dihydro-2H-[1,4]benzodiazepines-2-one for manufacturing application is of great scientific and practical interest.

The purpose of our work is to search for a rational method to synthesize the target product, experimental study of the chemical processes to develop the most optimal methods to produce the product.

The technology to produce 1-methyl-5-phenyl-7-chlor-1,3-dihydro-2H-[1,4]-benzodiazepine-2-one on an industrial scale was developed.

The synthesis of 2-benzoyl-2',4-dichloro- $N$-methylacetanilide by condensation of 2-methylamine-5chlorobenzophenone with chloracetyl chloride in carbon tetrachloride without further treatment of the reaction mass with water and sodium carbonate was developed.

The highest yield of 1-methyl-5-phenyl-7-chlorine-1,3-dihydro-2H-[1,4]-benzodiazepines-2-one was shown to be obtained if the cyclization reaction is carried out in isopropyl alcohol. The reaction mixture composition in interaction of 2-benzoyl- 2',4 -dichloro- $N$-methylacetanilide with urotropin plays the defining role in the formation of the target product.
\end{abstract}

\section{References}

[1] V.G. Belikov. Synthetic and Natural Medicinal Products. Moscow: Higher school. 1993. Vol.1. P.64. (russian)

[2] M.D. Mashkovskiy. Medicinal Products. Edition 15th, revised., correct. and add. Moscow: OOO "Publishing House New Wave». 2019. P.75. (russian)

[3] N.I. Lyukshenko, B.V. Pevchenko, R.G. Nikitin. XV-th International conference High Energy and Special Materials (HEMs-2019): demilitarization, antiterrorism and civil applications. 2019. (russian)

[4] V.G. Granik. Fundamentals of Medical Chemistry. Moscow: University book. 2001. P.384. (russian)

[5] T. Gilchrist. Chemistry of heterocyclic compounds: trans. from English. Moscow: World. 1996. P.446. (russian)

[6] A.A. Litvin, G.B. Kolyvanov, V.P. Zherdev, A.P. Arzamastsev. The relationship between the physicochemical properties and pharmacokinetic parameters of 1,4-benzodiazepine derivatives. Pharmaceutical Chemistry Journal. 2004. No.11. P.3-5. (russian)

[7] Patent No. 26875556. Lyukshenko N.I. The method of obtaining 7-chloro-1,3-dihydro-1-methyl-5phenyl-1H-1,4-benzodiazepin-2-one, 2018. (russian) 
NEW TECHNOLOGY TO OBTAIN 1-METHYL-5-PNENYL-7-CHLORO-1,3-DIHYDRO-2H-[1,4]-BENZODIAZEPINE-2-ONE 24-31

[8] Patent No. 2703309. N.I. Lyukshenko, B.V. Pevchenko, R.G. Nikitin, V.N. Belyaev. A method of obtaining 2-methylamino-5-chlorobenzophenone, 2019. (russian)

[9] FS 001719-151217. Diazepam. The implementation deadline is 15.12.17.

[10] R.G. Nikitin, N.I. Luykshenko. Proceedings of 5th all-Russian research-to-practice conference of young scientists and professionals "Materials and Technologies of the 21st century" 2019. Vol.1. P.156.

[11] V.G. Belikov. Synthetic and Natural Medicinal Products. Moscow: High school. 1993. Vol.2. P.565. (russian)

[12] D.A. Harkevich. Pharmacology. Moscow: Medicine. 1980. P.416. (russian)

[13] State Pharmacopeia. Ed. XIV. 2018. (russian)

[14] E. Lukewitz, L. Ignatovich. Heterocycles at the global pharmaceutical market. Riga: Org. Synthesis Institute. 1992. P.40.

[15] Register of medicinal products of Russia. Encyclopedia of remedies. Edited by G.L. Viyshkovskiy. Moscow: $L L C \ll R L S-2004 »$. 2018. P.2560. (russian)

[16] M. Hannonn, M. Zinic, D. Kolbah, N. Blazevic and F. Kajfez, J. Heterocycl. Synthesis of Imidazolidin4-ones and Their Conversion into 1,4-Benzodiazepin-2-ones. Chem. 1981. Vol.18. P.963.

[17] R.B. Silvermen. The Organic Chemistry of Drug Design and Drug Action. San Diego: Academic Press. 1992. $145 \mathrm{p}$.

[18] D. Barton and W.D. Ollis. Transl-ed from English by G. Ya. Kondratieva and Prof. N.S. Wolfson. General Organic Chemistry. Nitrogen-containing heterocycles. 1985. Vol.8. P.752. (russian)

[19] E. Demlov, Z. Demlov. Phase-transfer catalysis. Moscow: Mir. 1987. P.485. (russian)

[20] G.I. Zhungietu, V.G. Granik Main principles of drug designing. Kishinyev: Editing and polygraphic complex of the State University of Moldova Republic. 2000. P.350.

[21] P. Laslo. Organic synthesis logics. In 2 vol-s: transl-ed from French. Moscow: MIR. 1998. P.229. (russian)

[22] O.A. Rayevskiy, A.M. Sapegin, I.I. Kitov and al. Assessment of substituents effect on their psychotropic activity in 1,4-benzodiazepines. Chemical and Pharmaceutical journal. 1989. No.1. P.6266. (russian)

[23] R.P. Yevstigneeva. Delicate Organic Synthesis. Moscow: Chemistry. 1991. P.184. (russian) 